\title{
低熱ポルトランドセメントーフライアッシュ系材料の 強度発現や中性化抵抗性に及ぼす脱型材齢の影響と表層品質の非破壊評価
}

\author{
蔵重勲 ${ }^{* 1}$ 西田孝弘 ${ }^{* 1} \quad$ 廣永道彦 ${ }^{* 1}$
}

*1 財団法人電力中央研究所 地球工学研究所バックエンド研究センター( T270-1194 千葉県我孫子市我孫子 1646)

\begin{abstract}
要旨：低レベル放射性廃棄物の余裕深度処分施設への適用が検討されている低熱ポルトランドセメントフライアッシュ系材料を対象に、適切な養生による品質確保方法を提示することを目的として、脱型材齢 が強度発現や中性化抵抗性に及ぼす影響を実験的に評価した。その結果、脱型材齢が $7 、 14 、 28$ 日の順 に圧縮強度および静弹性係数が向上し、材齢 28 日まで型枠を存置した場合、脱型材齢 7 日に対して中性 化速度係数を抢よそ半減できることが分かった。また、表層透気係数は脱型材齢の異なる低熱ポルトラン ドセメントーフライアッシュ系材料についても中性化速度係数との強い相関が認められ、施工後品質検査 の一指標として有用であることを示した。
\end{abstract}

キーワード：放射性廃棄物処分、低熱ポルトランドセメント、フライアッシュ、脱型材齢、強度発現、中 性化抵抗性、表層品質、非破壊評価

\section{1. はじめに}

原子力発電は、火力発電等と比較して単位エネルギー 当たりの $\mathrm{CO}_{2}$ 排出量が非常に少ない特長があるが、加 工・再処理といった原子燃料サイクルや発電の各段階に おいて放射性廃棄物が発生する。このうち、放射能レベ ルの比較的低い廃棄物は、既に浅地中ピット処分の操業 に至っている ${ }^{1,2)}$ 。

放射能レベルの比較的高い廃棄物については、建物基 礎、地下鉄、共同溝等の一般的地下利用に対して十分な 安全裕度を持った深さ、例えば地下 $50 \sim 100 \mathrm{~m}$ 程度へ の埋設処分(余裕深度処分)が計画されて抢り、その施設 設計や安全評価検討が鋭意進められている ${ }^{3)}$ 。余裕深度 処分施設は、コンクリートピット内に定置された廃棄体 間にセメント系材料を充填し、外部に低拡散層(候補材 料としてモルタルが検討されている) 拉よび低透水層(べ ントナイト材料) といった人工バリアを配置し、岩盤な どの天然バリアとともに放射性核種の漏洩を抑制しよう とするものである ${ }^{4,5)}$ 。セメント系人工バリア(低拡散 層)には、放射性核種の移行抑制機能として低拡散性扔 よび収着性が期待され、低熱ポルトランドセメントーフ ライアッシュ系(以降、LPC-FA 系と略記) 材料の使用 や低水粉体比を志向した配合が検討されている。

特に、セメント系人工バリアには初期強度発現は比較 的要求されて㧍らず、むしろ長期水和反応による硬化体 の緻密化や温度応力などによるひび割れ発生の対策が重 要視され、フライアッシュについても単に副産物の有効 利用といった観点ではなく、そのポゾラン反応性や緻密
化に対する有効性を積極的に評価・活用しょうとしてい

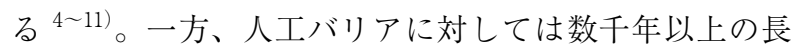
期的な性能変化を予測することが重要課題となってお $\eta^{12)}$ 、例えばセメント系材料の劣化現象として地下水 による溶脱が採り上げられ、空隙率と関連付けるなどし て拡散係数への影響が評価されている。

このような超長期耐久性の評価が必要な施設に対して は、一般構造物にも増して設計で考虑した要求性能が竣 工物において確実に満足されていることが肝要であり、 材料の品質変動や施工プロセスの適切な管理・検查方法 を確立しておく必要がある ${ }^{13)}$ 。また、より直接的な性 能確認の一助として、竣工構造物を対象とした非破壊試 験による品質検査も有効と考えられる。他方、施設閉鎖 後の維持管理が困難な処分施設においては、竣工時にお ける品質や性能の把握が、処分施設の安全性評価の観点 上、安全裕度の定量化や将来的な評価レヴューの実施に 寄与するものと期待される ${ }^{14)}$ 。

以上の背景から、本研究では、水和反応が比較的緩慢 でありながら脱型材齢など養生の影響について定量的な 知見にそしい LPC-FA 系材料を対象に、施工プロセス における影響因子としてインパクトが比較的大きいもの と想定される脱型材齢に着目し、強度発現や中性化抵抗 性への影響を実験的に評価した。また、施工プロセスや 竣工時の品質検查方法への適用性を調べる目的から、脱 型材齢が異なることによる品質の差異を非破壊試験に よって定量的に評価可能か調べた。 
Table 1 Mix proportion

\begin{tabular}{|c|c|c|c|c|c|c|c|c|c|c|c|c|c|}
\hline \multirow{2}{*}{ Type } & \multirow{2}{*}{$\begin{array}{l}\mathrm{W} / \mathrm{B} \\
(\%)\end{array}$} & \multirow{2}{*}{$\begin{array}{l}\mathrm{W} / \mathrm{P} \\
(\%)\end{array}$} & \multirow{2}{*}{$\begin{array}{l}\mathrm{s} / \mathrm{a} \\
(\%)\end{array}$} & \multirow{2}{*}{$\begin{array}{c}\mathrm{SP} \\
(\% \times \mathrm{P})\end{array}$} & \multicolumn{7}{|c|}{ Unit content $\left(\mathrm{kg} / \mathrm{m}^{3}\right)$} & \multicolumn{2}{|c|}{ Target values } \\
\hline & & & & & $\mathrm{W}$ & LPC & $\mathrm{FA}$ & $\mathrm{EX}$ & LS & $\mathrm{S}$ & G & Flow $(\mathrm{cm})$ & Air (\%) \\
\hline $\mathrm{LFc}$ & \multirow{2}{*}{45.0} & 30.0 & 53.4 & 0.94 & 160 & 229 & 107 & 20 & 178 & 884 & 780 & \multirow{2}{*}{$65 \pm 5$} & \multirow{2}{*}{$2.5 \pm 1.5$} \\
\hline LFm & & 31.0 & - & 0.68 & 230 & 338 & 153 & 20 & 230 & 1279 & - & & \\
\hline
\end{tabular}

$\mathrm{B}:$ Binder $(\mathrm{LPC}+\mathrm{FA}+\mathrm{EX}), \mathrm{P}:$ Powder $(\mathrm{LPC}+\mathrm{FA}+\mathrm{EX}+\mathrm{LS})$, SP : Air-entraining and high-range water-reducing admixture, W : Water, LPC : Low-heat Portland cement (density $: 3.22 \mathrm{~g} / \mathrm{cm}^{3}$, specific surface area $: 3630 \mathrm{~cm}^{2} / \mathrm{g}$ ), FA : Fly ash (Class II, density $: 2.15 \mathrm{~g} / \mathrm{cm}^{3}$, specific surface area $: 3850 \mathrm{~cm}^{2} / \mathrm{g}$, LOI $: 1.2 \%, \mathrm{SiO}_{2}$ content $: 58.9 \%$ ), EX $:$ Expansive additive (density $: 3.05 \mathrm{~g} / \mathrm{cm}^{3}$, specific surface area $: 4380 \mathrm{~cm}^{2} / \mathrm{g}$ ), LS $: \mathrm{Lime}$ stone powder (density $: 2.73 \mathrm{~g} / \mathrm{cm}^{3}$, specific surface area $: 5990 \mathrm{~cm}^{2} / \mathrm{g}$ ), S: Fine aggregate (lime stone sand, density in SSD condition $: 2.66 \mathrm{~g} / \mathrm{cm}^{3}$, absorption : $1.15 \%$, F. M. : 2.76, solid content : $63.2 \%$ ), G : Coarse aggregate (lime stone gravel, density in SSD condition : $2.69 \mathrm{~g} / \mathrm{cm}^{3}$, absorption : $0.42 \%$, F. M. : 6.64 , solid content : $61.1 \%)$

Table 2 Demolding ages, specimen codes and exposure condition

\begin{tabular}{|c|c|c|c|c|}
\hline \multicolumn{2}{|c|}{ Demolding age } & 7 -day & 14-day & 28-day \\
\hline \multirow{2}{*}{ Code } & LFc $: C$ & $C 7$ & $C 14$ & $C 28$ \\
\cline { 2 - 5 } & LFm $: M$ & $M 7$ & $M 14$ & $M 28$ \\
\hline $\begin{array}{c}\text { Exposure condition after } \\
\text { demolding }\end{array}$ & \multicolumn{2}{|c|}{$20 \pm 2{ }^{\circ} \mathrm{C}, 60 \pm 5 \% \mathrm{RH}$} \\
\hline
\end{tabular}

\section{2. 実験概要}

脱型材齢が強度発現に及ぼす影響の評価指標として圧 縮強度および静弾性係数を選定した。耐久性や物質移動 抵抗性に関連する指標としては、養生の影響を受けやす い中性化抵抗性に着目し、著者らのこれまでの検討 ${ }^{15)}$ により表層から内部への品質分布を評価できる可能性が 示されている促進中性化試験によって、脱型材齢の影響 を調べた。また、脱型材齢が表層品質に及ぼす影響、な らびに非破壊評価によって養生の良否を判定可能か調べ るため、強度特性評価法として実績のあるリバウンドハ ンマー試験と物質移動抵抗性評価法の一つとして有望視 される Torrent 法表層透気試験 ${ }^{16)}$ を採用し、両非破壊 試験法の適用性を評価した ${ }^{17,18)}$ 。

Table 1 に示す配合の LPC-FA 系のコンクリートお よびモルタルを用い、圧縮強度および静弾性係数測定 用に $\phi 10 \times 20 \mathrm{~cm}$ 円柱供試体、促進中性化試験用に $10 \times$ $10 \times 40 \mathrm{~cm}$ 角柱供試体、また非破壊試験用に $15 \times 15 \times$ $53 \mathrm{~cm}$ 角柱供試体をそれぞれ作製した。各供試体は、材 齢 7、14、28 日においてそれぞれ脱型し(促進中性化試 験用供試体は脱型材齢 7、28 日のみ)、気温 $20 \pm 2{ }^{\circ} \mathrm{C}$ 、 相対湿度 $60 \pm 5 \%$ の䨌囲気に曝露した (Table 2)。なお、 脱型材齢の影響は温湿度等曝露䨌囲気の条件によって異 なるが、本研究ではまず平均的な温湿度の一様䨌囲気へ の曝露によってその影響を把握することを目的とした。 地下トンネル等、比較的湿度の高い環境での影響につい ても別途評価検討中である。

圧縮強度・静弾性係数の測定方法はJISに準拠し た。促進中性化試験は、各供試体を材齢 91 日まで Table 2 の雲囲気に曝露した後、気温 $20{ }^{\circ} \mathrm{C}$ 、相対湿 度 $60 \%$ 、 $\mathrm{CO}_{2}$ 濃度 $5 \%$ の条件で促進期間 91 日まで 実施した。また、リバウンドハンマー試験については JSCE-G504-2007 の方法に従って、供試体を平滑な剛版 上に定置した状態で鉛直方向に打撃し、供試体あたり 20 点 1 回の測定で基準反発度を求めた。Torrent 法表

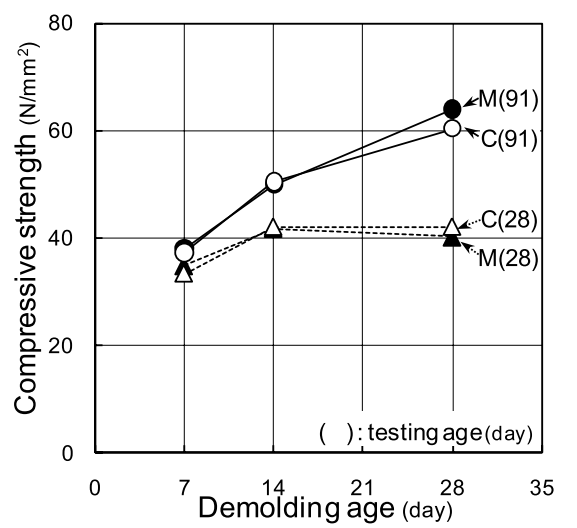

Fig. 1 Effects of demolding age on the development of compressive strength

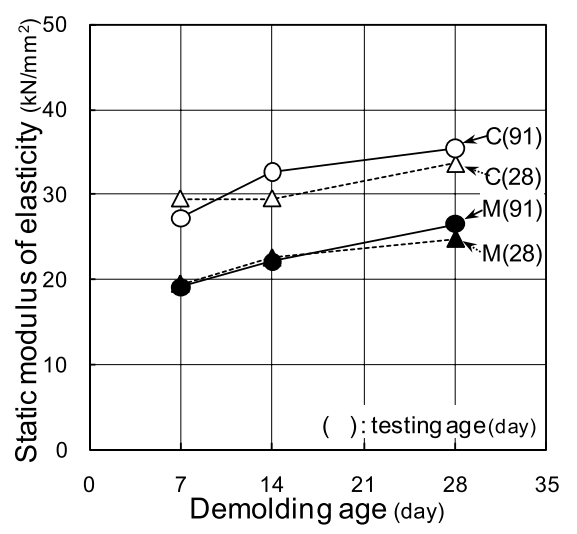

Fig. 2 Effects of demolding age on the development of elastic modulus

層透気試験は、チャンバー内初期圧 $30 \mathrm{mbar}$ の設定条 件で、供試体の $15 \times 53 \mathrm{~cm}$ 両側面の中央部で 1 回ずつ 行って平均值を測定結果とし、含水の影響を考慮するた めWenner 法(電極間隔 $5 \mathrm{~cm}$ )によって電気抵抗率の測 定も行った。

\section{3. 強度発現や中性化抵抗性に及ぼす脱型材齢の 影響}

\section{1 圧縮強度および静弾性係数への影響}

Fig. 1、2 に、材齢 28、91 日における圧縮強度および 静弾性係数に及ぼす脱型材齢の影響をそれぞれ示す。材 齢 28 日の圧縮強度では、脱型材齢 7 日の場合に若干小 さくなったが、材齢 91 日では脱型材齢が遅くなるほど 強度増進が大きく、脱型材齢の顕著な影響が認められた。 また、同水結合材比である LFc および LFm は、同等 の強度発現性を持っていることを確認できた。なお、材 


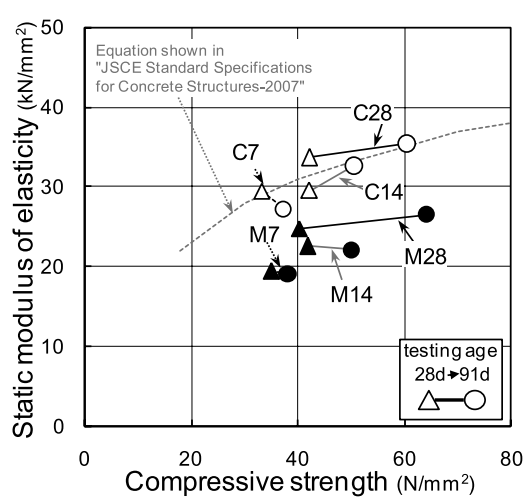

Fig. 3 Relationship between compressive strength and static modulus of elasticity

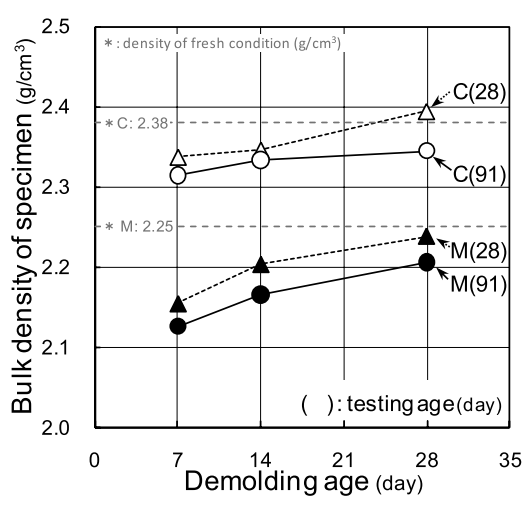

Fig. 4 Effects of demolding age on the bulk density of specimens

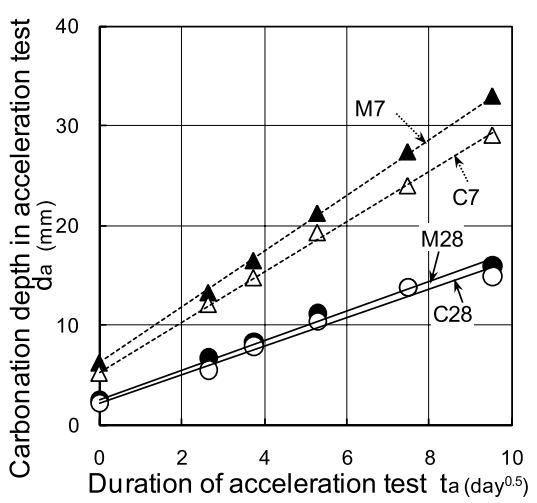

Fig. 5 Linear relationship of carbonation depth to the square root of duration
齢 28 日にて脱型し、同材齢において圧縮強度を測定し た場合は、比較的含水率が高い条件のため見かけ上、測 定值が低くなっている可能性が考えられる。

静弾性係数については、LFm より粗骨材を含む LFc で高い值を示し、脱型材齢が遅くなるほど大きくなっ た。これら圧縮強度と静弾性係数の関係を、コンクリー ト標準示方書に記載されている両者の関係式とともに Fig. 3 に示す。LFc の圧縮強度と静弾性係数の関係は、 一般的なコンクリートと同様であることが確認された。 LFm は粗骨材を含まないことから、静弾性係数は 3 割 程度低い值を示した。

水和反応が緩慢な LPC-FA 系材料では、脱型材齢を 7、 14、28 日と遅らせることで水和反応に必要な水分の逸 散を抑制し、強度発現性を向上可能なことを示した。こ れに関して実際の水分逸散量を比較・確認するため、脱 型材齢と供試体のかさ密度の関係を整理した (Fig. 4)。 その結果、単位容積質量と比較したかさ密度の低下量は、 脱型時期を遅らせることで小さくなることが定量的に示 された。コンクリート標準示方書施工編の施工標準で は、セメント種類や環境温度に応じた湿潤養生期間の標 準が示されているが、LPC-FA 系の潜在的強度を十分 に発揮させるには、脱型材齢を 14 日よりも長く取るこ とが有効であることが分かった。他方、本実験で行った 強度評価は $\phi 10 \times 20 \mathrm{~cm}$ の円柱供試体を用いたものであ る。実際には、脱型材齢の影響は表層に留まるため部材 深部の強度とは必ずしも一致しないが、このような脱型 材齢の影響がどの程度の領域まで及ぶものか、LPC-FA 系材料についても把握する必要があると考えられ る 19, 20)。

\section{2 中性化抵抗性への影響}

Fig. 5 は、促進中性化試験における中性化深さの変化 を促進期間の平方根と対比したものであり、脱型材齢が 7 日の場合には、28日に比べて中性化抵抗性が明らか に劣ることが分かる。この結果について、後述する試験 開始時の中性化深さを切片とした $\sqrt{\mathrm{t}}$ 式に基づき、促 進中性化速度係数を算出して比較してみると、Fig. 6 の ように材齢 7 日に脱型した場合はおよそ 1.7 倍に増大

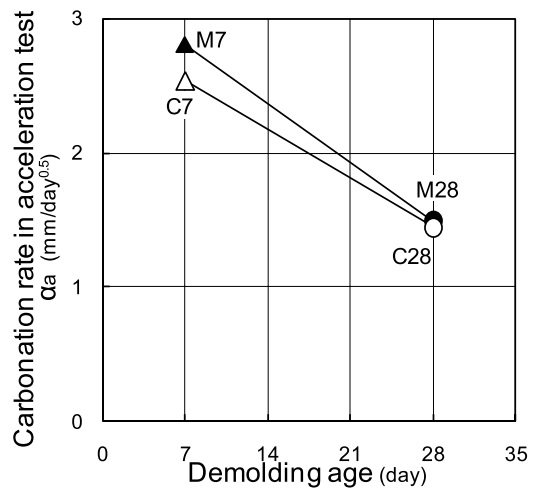

Fig. 6 Effects of demolding age on carbonation rates in acceleration test

することが分かった。また、水結合材比が同じ LFc と LFm では、脱型材齢が 28 日の場合、同程度の中性化 抵抗性を示したが、脱型材齢 7 日では LFm の促進中 性化速度係数が比較的大きくなった。これは、粗骨材の 存在により $\mathrm{CO}_{2}$ の侵入に対する屈曲性が増加すること に起因すると考えられるが、材齢 7 日に脱型した場合は、 若材齢における水分の逸散により表層における水和反応 が阻害され、その結果、比較的連結性の高い空隙構造が 形成されたことによって、顕著な差が表れたものと考え られる。

一方、Fig. 5 で示されるように、促進中性化試験の開 始時において既に数 $\mathrm{mm}$ 程度の深さまで中性化が進行 していることが分かる。供試体は脱型後、気温 $20{ }^{\circ} \mathrm{C} 、$ 相対湿度 $60 \%$ の䨌囲気に曝されていたが、このような 環境下で、脱型材齢が 28 日の供試体においても、中性 化の進行が認められたことは特筆すべきである。Fig. 7 は、前述の大気環境における中性化速度係数を、促進中 性化試験開始時の中性化深さと脱型後大気に曝されてい た期間から算出し、脱型材齢との関係を調べたものであ る。促進中性化速度係数と同様に、脱型材齢が遅いほど 小さく、LFm で若干大きな值を示した。これらの大気 環境下の中性化速度係数は、Fig. 5 で示したようにごく 表層の中性化結果に基づいて算出されたものである。つ まり、脱型材齢に応じて内部の品質とは異なった領域に おける評価值であり、これを代表值として長期の中性化 


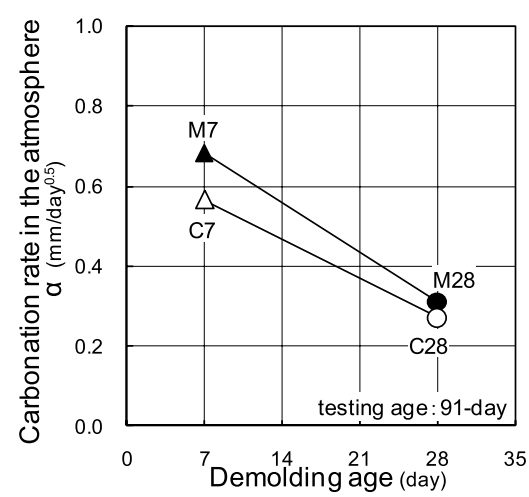

Fig. 7 Effects of demolding age on carbonation rates in the atmosphere

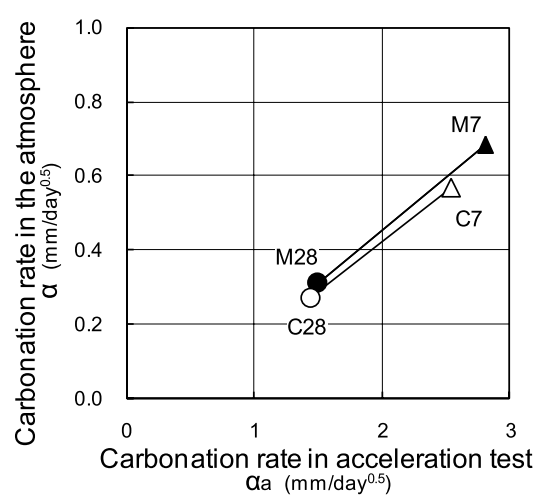

Fig. 8 Comparison of carbonation rate in acceleration test to that in the atmosphere

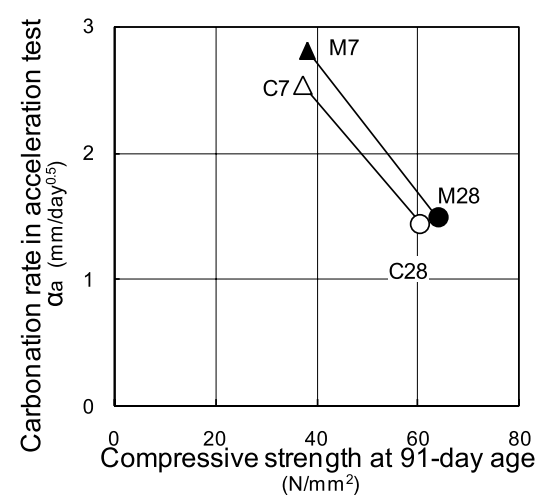

Fig. 9 Correlation of compressive strength at 91-day age to carbonation rate in acceleration test
予測に単純に用いることは危険である。これに関して Fig. 5 で例示すれば、脱型材齢 28 日の供試体の中性化 進行は内部に及ぶほど鈍化する傾向が認められ、表層か ら内部への品質変化を示唆するものと考えられる ${ }^{15)}$ 。

このような品質分布に関する問題が指摘されるが、中 性化進行が 15 30mm 程度までの今回の実験結果にお いては、深さの違いによる中性化速度係数の差異はそれ ほど大きくないとして、大気環境に打ける中性化速度倸 数と促進中性化速度係数を Fig. 8 で比較した。両者は 比例関係にあることが認められ、促進中性化速度係数は、 大気中の值に対して 3.6 倍程度となった。ここで、炭 酸ガス濃度が中性化進行に及ほす影響を定式化している 魚本・高田式 ${ }^{21}$ を用いて、 $\mathrm{CO}_{2}$ 濃度 $5 \%$ 条件の促進倍 率を求めたところ、拈よそ 4.9 倍となった。魚本・高 田式では普通ポルトランドセメントを用いたコンクリー トのデー夕に基づいているため単純な比較は難しいが、 本実験結果がより小さな值となったのは、前述のと抢り 大気中の中性化速度係数がごく表層における中性化深さ に基づいて算出されたものであり、促進中性化速度係数 を求めた場合と比較し、品質が比較的低い領域の中性化 抵抗性を評価していることも一因として挙げられる。

\section{3 圧縮強度と促進中性化速度係数の関係}

脱型材齢に応じて変化する強度特性と中性化抵抗性の 関係を整理するために、促進中性化試験開始時の材齢 91 日に打ける圧縮強度と促進中性化速度係数を Fig. 9 で比較した。圧縮強度の増分に対する促進中性化速度係 数の低減量は LFc と LFm で大差は無かったが、脱型 材齢が 7 日から 28 日と変わった場合の圧縮強度や促進 中性化速度係数の変化幅は LFm で大きくなった。この ことからモルタルである LFm の方が、強度発現性や中 性化抵抗性に打いて脱型材齢の影響を受けやすいと言え る。なお、このような比較をする場合には、脱型材齢に 応じて樑さ方向に品質分布を生じることを考慮し、特に 圧縮強度においては測定に用いる供試体の寸法の影響を 加味する必要がある。すなわち、圧縮強度試験が品質分 布を平均的に評価する性質を持つものに対して、促進中 性化試験は表面から内部へ進行する現象を追跡したもの

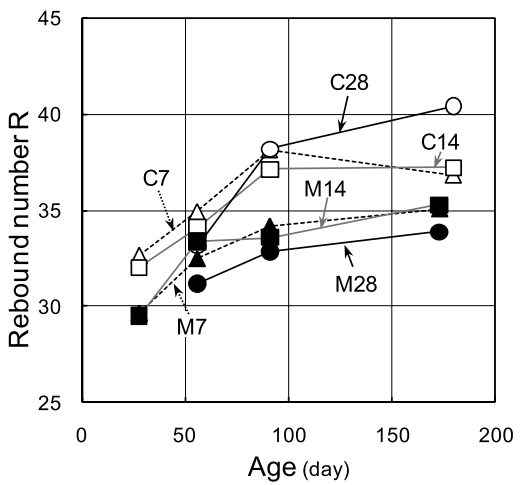

Fig. 10 Changes of rebound number with age

であり、両者の対比に当たってはその結果の普遍性を如 何にして説明するかが重要になるものと考えられる ${ }^{22) 。 ~}$

\section{4. 脱型材齢が表層品質に及ぼす影響の非破壊評 価}

\section{1 基準反発度および表層透気係数の測定結果}

脱型材齢や養生に関する施工プロセスの適切な管理に より表層品質を確保することは重要であるが、竣工時に 定量的な評価を行うことも、先に述べたように処分施設 の性能確認や将来的な評価レヴューにとって有用と考元 られる。ここでは、脱型材齢の異なる各種供試体に対し て測定した基準反発度と表層透気係数の結果を示し、表 層品質評価の指標や方法について考察した。な㧍、前章 で述べたと㧍り脱型材龄に関しては、その影響が表層か ら内部へと及ぶことから、非破壊試験によって部材表面 から表層品質を如何にして評価可能か調べることが課題 となる。この点についても多少言及した。

Fig. 10 は、基準反発度の材齢約 180 日までの経時変 化を示したものである。脱型材齢がいずれの場合でも基 準反発度は増加傾向にあるが、圧縮強度等の測定結果で 見られた脱型材齢に応じた大小関係とは一致しないこと が分かった。これは、Fig. 5 で明らかにしたように大気 環境に拀いて進行した中性化が影響しているものと考 えられる。三井らは、中性化深さが数 $\mathrm{mm}$ の場合でも 基準反発度に有意な影響を及ぼす実験結果を示してお 
$り^{23)}$ 、本研究においても脱型材齢 7 日の場合には材齢 91 日で約 $6 \mathrm{~mm}$ 、脱型材齢 28 日で同じく約 $2 \mathrm{~mm}$ の中 性化深さが認められた。したがって、より早期の脱型に よって表層品質は低下するものの中性化が早期に進行し たため、基準反発度が比較的大きな值として測定され、 脱型材齢の明確な影響が見られなかったものと考えられ る。なお、基準反発度は LFm より LFc で相対的に大 きな值を示し、弾塑性的な衝撃問題を取り扱うリバウン ドハンマー試験から得られる基準反発度は、圧縮強度 よりも静弾性係数との相関が強いものと推察される ${ }^{22)}$ (Fig. 1、2 参照)。

一方、表層透気係数の材齢約 180 日までの経時変化 (Fig. 11) を見ると、脱型材齢の影響が明瞭に表れてお り、脱型時期が早いほど表層透気性が増大していること が分かる。表層透気係数の経時変化に着目すると、材齢 とともに上昇する傾向が、いずれの供試体においても確 認される。これは、気温 $20{ }^{\circ} \mathrm{C}$ 、相対湿度 $60 \%$ の大気 環境下で供試体中の水分が徐々に逸散し、透気経路とな る空隙の割合が増加したためと考えられる。Fig. 12 は その推論を検証する一つの実験結果であり、供試体表面 から非破壊測定した電気抵抗率の経時变化である。いず れの供試体においても電気抵抗率が上昇する様子が認め られ、特に脱型材齢 7 日の場合には早期の水分逸散が 顕著であり、材齢約 180 日では今回用いた装置の測定 限界である $2000 \mathrm{k} \Omega \mathrm{cm}$ 以上の值となった。このように、 表層透気係数の測定に当たっては、供試体の含水状態の 影響を受け、材齢が初期であるほど見かけ上小さな測定 值を示すことから、危険側の評価とならないよう、含水 状態の適切な評価とともに、透気性に及ぼす影響を十分 に考慮する必要があると言える 14, 16, 22, 24)。

以上、基準反発度や表層透気係数の経時変化に着目し て考察を述べたが、脱型材齢の影響をより詳細に比較す るために両者の関係を Fig. 13 および 14 にそれぞれ示 した。基準反発度は、中性化の影響を受け、早期の脱型 による表層品質の低下とは相反する傾向が確認された。 一方、表層透気係数は脱型材齢が若いほど大きな值を示 し、材齢約 180 日における測定值で比べると、脱型材 齢を 7 日から 14 日に、また 7 日から 28 日に遅らせる ことで表層透気係数をそれぞれ約 1/5、および約 $1 / 25$ の值まで低減できることが明らかとなった。

ここで、基準反発度の測定結果で見られた中性化の影 響は、表層透気係数に対しては明瞭でなかった。これは、 リバウンドハンマー試験がごく表層の弾塑性的な物性に 依存した非破壊試験方法であるのに対して、Torrent 法 表層透気試験はダブルチャンバー法 ${ }^{25)}$ としての原理上、 比較的内部の品質をも包含した評価結果が出力される方 法であると解釈できる。事実、中性化の有無によって反 発度は変化するが、表層透気係数の測定結果にはそれほ ど差異が認められない実験結果が報告されている ${ }^{14)} 。$

\section{2 非破壊測定值と圧縮強度や中性化抵抗性の関係} 竣工した構造物が保有する強度発現性や物質移動抵抗

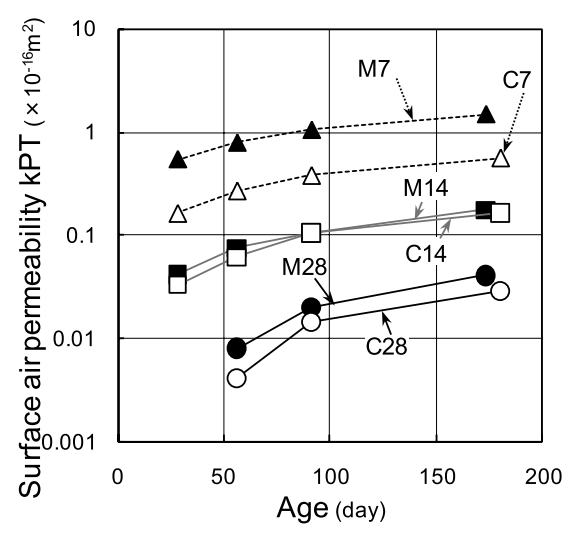

Fig. 11 Changes of surface air permeability with age

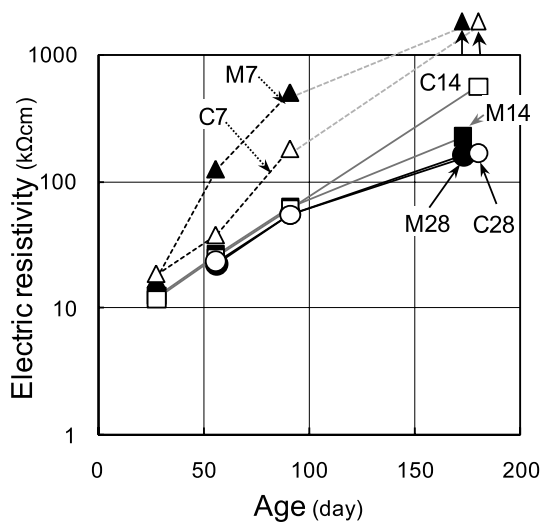

Fig. 12 Changes of electric resistivity with age

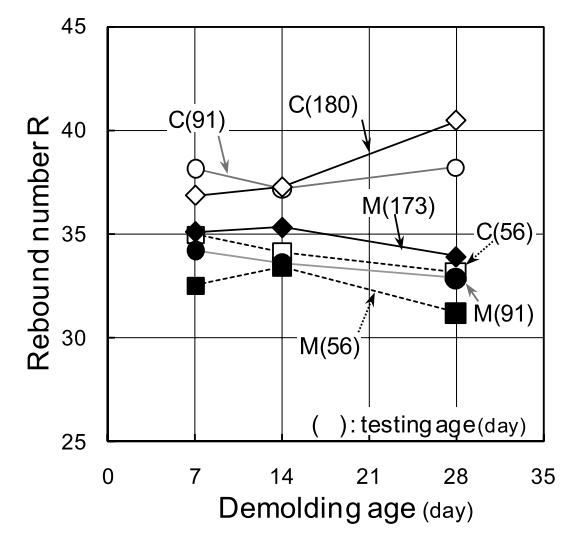

Fig. 13 Results of the rebound number of specimens demolded at the deferent ages

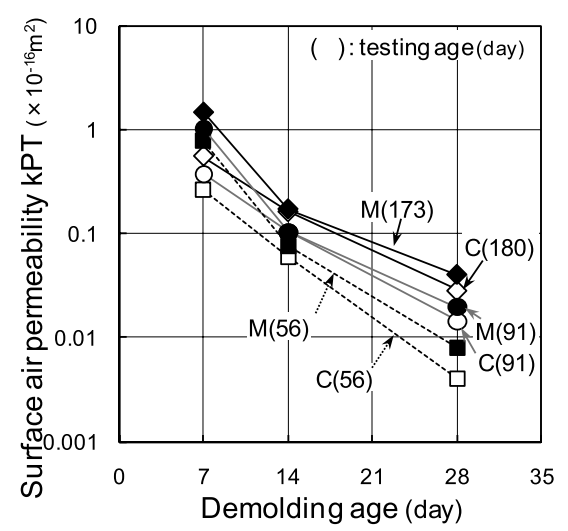

Fig. 14 Results of the surface air permeability of specimens demolded at the deferent ages 
性を、非破壊的に評価可能か調べるため、前節で示した 非破壞測定值と圧縮強度や中性化抵抗性の関係を分析し た。Fig. 15 に、各材齢でそれぞれ測定した基準反発度 と圧縮強度の関係を示す。従来、圧縮強度を非破壊推定 するために基準反発度を説明変数とした様々な推定式が 提案されているが ${ }^{17)}$ 、本研究で対象としたような配合 の LPC-FA 系材料では、大気環境中においても早期に 中性化が進行してしまい、供試体の平均的な品質を評価 するような圧縮強度と、ごく表層の品質に敏感な基準反 発度の間には、明確な比例関係が認められなかった。

Fig. 16 は、同じく基準反発度と促進中性化速度係数 を比較したものであるが、相関性は弱い結果となった。 これも上記の考察と同様に、非破壊測定した基準反発度 が中性化の影響を受けて、脱型材齢の影響による品質の 差異を適確に捉えられなかったことに起因するものであ る。

一方、材齢 91 日に測定した表層透気係数と促進中 性化速度係数の関係を Fig. 17 に、また大気環境におけ る中性化速度係数との関係を Fig. 18 に示す。両中性化 速度係数ともに、表層透気係数と強い相関が認められ、 LFc および LFm において、ほぼ同一の関係式で表され る結果となった。この様に、粗骨材の有無の違いがある にも拘らずほぼ同様な関係となった理由の一つとして、 結合材種類および水結合材比が同一であったことが考え られる。中性化抵抗性は、 $\mathrm{CO}_{2}$ の侵入に対する抵抗性 のみならず、 $\mathrm{CO}_{2}$ と反応して消費される水和物の相組 成など化学的性質にも依存することから、結合材種類が 異なる場合は同一の関係式で表すことはできないと言え る。また、水結合材比についても、脱型材齢が表層品質 に及ぼす影響程度が異なる可能性があり、表層透気係数 と中性化速度係数の関係を別途検証する必要がある。

しかし、本研究で対象とした LPC-FA 系材料を用い た今回の配合においては、脱型材齢が表層品質に及ぼ す影響を、Torrent 法表層透気試験によって定量的に評 価することができることが分かり、施工のプロセス検査 や竣工時の性能確認試験に適用できる可能性が見出され た。例えば、施工計画において取り決めた脱型材齢に応 じ、表層透気係数の判定基準值などを予設定しておき、 実際の構造物に対して測定した表層透気係数との対比に よって品質の確認を行うなどの方法が挙げられる。今回 の検討では、曝露環境を気温 $20{ }^{\circ} \mathrm{C} 、$ 相対湿度 $60 \%$ といっ た一様雲囲気としたが、実際にはこれとは異なるレベル の温湿度やそれらの変動が想定されることから、環境条 件の相違を考慮した検討が今後必要である。また、構造 物表面から実施する非破壊測定においては難しい問題で はあるが、脱型材齢の影響が及んでいる構造物内部の領 域を特定する評価検討も重要と考えられる。

最後に、本研究で一連して取り上げた中性化速度係数 は、あくまで材齢 91 日以降の促進中性化試験等で測定 された結果であり、脱型材齢に応じた表層品質の変化を 捉えるための一評価指標として用いたものである。すな

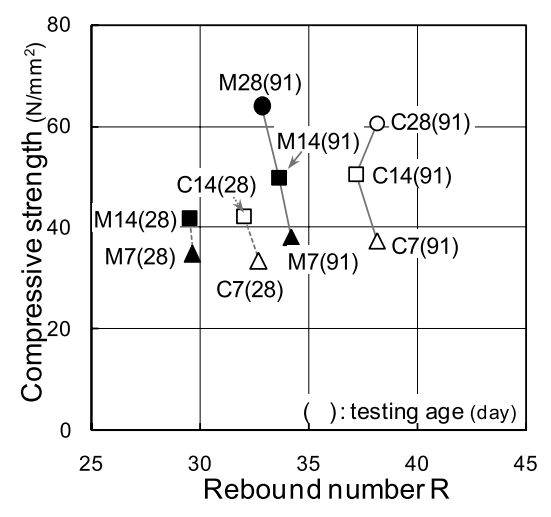

Fig. 15 Relationship between rebound number and compressive strength

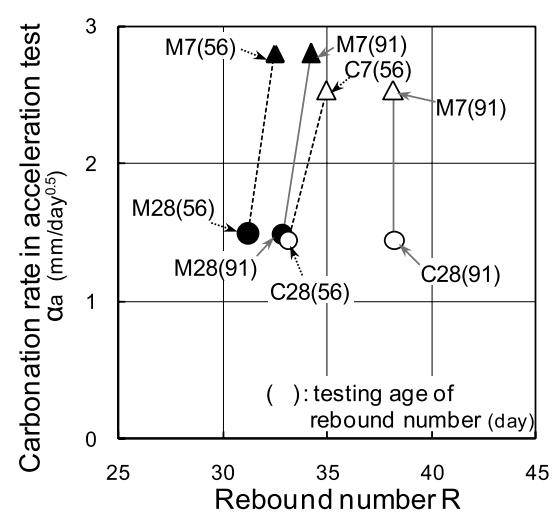

Fig. 16 Relationship between rebound number and carbonation rate in acceleration test

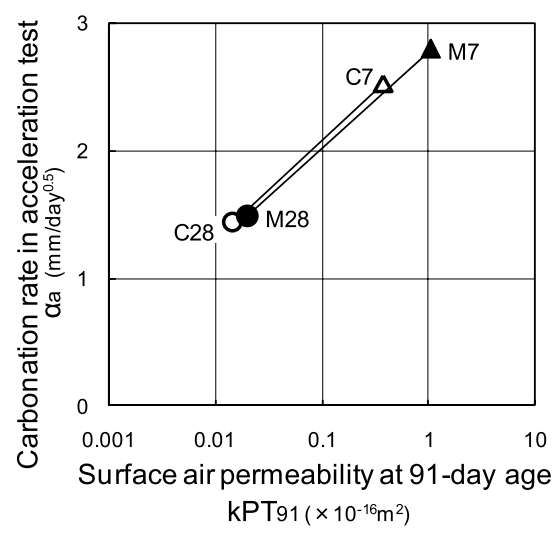

Fig. 17 Correlation of surface air permeability to carbonation rate in acceleration test

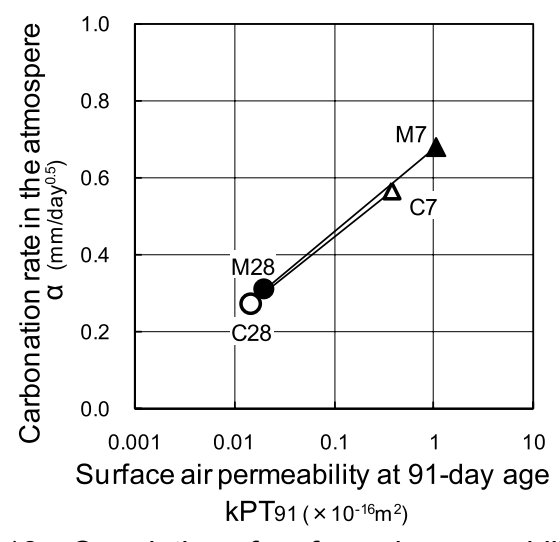

Fig. 18 Correlation of surface air permeability to carbonation rate in the atmosphere 
わち、実環境中における中性化の進行とは単純に対応関 係を明示することは難しく、 $\mathrm{CO}_{2}$ 濃度、気温、湿度な ど環境条件の相違や、水和反応の進行度の違いなどの影 響を的確に考慮する必要がある。

\section{5. まとめ}

以上、低レベル放射性廃棄物の余裕深度処分への適用 が検討されている LPC-FA 系材料の配合を対象に、脱 型材齢が強度発現や中性化抵抗性に及ぼす影響を実験的 に調べ、基準反発度や表層透気係数といった非破壊測定 值との対応を分析した。以下、主要な結論を列挙する。

（1）今回検討した水和反応が比較的緩慢な LPC-FA 系 材料を用いた配合の潜在的な強度発現性や中性化抵 抗性を発揮させるには、型枠存置期間 7 日では不 十分であり、脱型材齢を 14 日以降に遅らせること が有効である。特に、表層品質と関連がある中性化 抵抗性については、脱型材齢を 7 日から 28 日とす ることで中性化速度係数をおよそ半減できることが 分かった。

（2）強度特性の非破壊評価法として実績が豊富なリバウ ンドハンマー試験によって測定される基準反発度 は、大気環境下において進行した中性化によって、 脱型材齢に応じた品質 (圧縮強度、促進中性化速度 係数、表層透気係数)の変化とは相反する測定值が 得られた。今回対象とした LPC-FA 系材料など早 期に中性化が進行し易い配合については、中性化の 影響を適切に考慮して基準反発度の評価を行う必要 がある。

（3）物質移動抵抗性の非破壊評価が可能な Torrent 法 表層透気試験によって測定される表層透気係数は、 含水状態の影響を適切に考慮する必要はあるが、中 性化速度係数と強い相関が認められ、施工のプロセ ス検査や竣工時の性能確認試験に適用できる可能性 を見出した。

\section{謝辞：}

本研究で用いた実験供試体は、経済産業省からの委託 による「管理型処分技術調査等委託費(地下空洞型処分 施設性能確証試験)」((公財) 原子力環境整備促進 - 資金 管理センター受託)において使用した低熱ポルトランド セメントーフライアッシュ系のコンクリートおよびモル タルをご提供頂き作製したものです。関係各位に深甚の 謝意を表します。

\section{参考文献：}

1）田村明男、秋山吉弘：低レベル放射性廃棄物埋設施 設で活用されるセメント・コンクリート、セメント・ コンクリート、No. 620、pp. 30-35（1998）

2）日本原燃(株)低レベル放射性廃革物埋設センター Web : http://www.jnfl.co.jp/business-cycle/2_ maisetsu/maisetsu_03/maisetsu_03_02.html
3）低レベル放射性廃棄物の次期埋設に関する本格調査 結果について、日本原燃(株)プレスリリース資料、 http://www.jnfl.co.jp/press/pressj2006/pr060901-1. html (2006)

4）京谷修：放射性廃棄物処分施設の設計検討状況、土 木学会平成 17 年度全国大会研究討論会資料「コン クリート構造物の超長期耐久性評価 -1 万年コンク リートへの挑戦－」、pp. 9-11（2005）

5）庭瀬一仁、廣永道彦、辻幸和：低レベル放射性廃棄 物処分施設に用いるコンクリートの設計について、 コンクリート工学、Vol. 44、No.2、pp. 3-8（2006）

6）堀江正人ほか：余裕深度処分における人工バリアの 現場施工性確認試験の全体計画、土木学会第 62 回 年次学術講演会講演概要集、CS5-032、pp. 223-224 (2007)

7）田中博一ほか：低熱ポルトランドセメントと混和材 を併用したコンクリートの諸物性、コンクリート工 学年次論文集、Vol. 29、No. 1、pp. 735-740（2007）

8）庭瀬一仁ほか：低熱ポルトランドセメントとフライ アッシュ、膨張材を使用したコンクリートおよび モルタルの材齢 2 年までの諸特性（その 1)、土木 学会第 64 回年次学術講演会講演概要集、CS5-026、 pp. 185-186（2009）

9）杉橋直行ほか：低熱ポルトランドセメントとフライ アッシュ、膨張材を使用したコンクリートおよび モルタルの材齢 2 年までの諸特性（その 2)、土木 学会第 64 回年次学術講演会講演概要集、CS5-027、 pp. 187-188 (2009)

10）坪谷隆夫ほか：地下空洞型処分施設性能確証試験 計画概要 - 、土木学会第 62 回年次学術講演会講演 概要集、CS5-073、pp. 305-306（2007）

11）寺田賢二ほか：地下空洞型処分施設性能確証試験の 成果概要についてー平成 20 年度実施分を中心とし て 一、土木学会第 64 回年次学術講演会講演概要集、 CS5-014、pp. 161-162（2009）

12）余裕深度処分の安全評価における地下水シナリオに 用いる核種移行評価パラメー夕設定の考え方、土木 学会エネルギー委員会（2008）

13）余裕深度処分における地下施設の設計・品質管理お よび検査の考え方、土木学会エネルギー土木委員会 (2009)

14）蔵重勲ほか：放射性廃棄物処分施設におけるセメン ト系材料の品質検査システムの構築（その 1）-コ ンクリート表層の反発度ならびに透気性の非破壊評 価一、電力中央研究所報告、研究報告 N08081（2009）

15）蔵重勲、廣永道彦：養生条件が異なるコンクリート の促進中性化速度係数と非破壊測定した表層透気係 数の相関、土木学会第 65 回年次学術講演会講演概 要集、V-305、pp. 609-610（2010）

16) R. J. Torrent and L. Fernandez Luco: RILEM Report 40 Non-Destructive Evaluation of the Pen- 
etrability and Thickness of the Concrete Cover, State of the Art Report of RILEM Technical Committee TC 189-NEC : 'Non-destructive Evaluation of the Concrete Cover' (2007)

17）構造物表面のコンクリート品質と耐久性能検証シス テム研究小委員会（335 委員会）成果報告書、土木 学会コンクリート技術シリーズ 80 (2008)

18）歴代構造物品質評価／品質検査制度研究小委員会 （216 委員会）成果報告書、土木学会コンクリート 技術シリーズ 87 (2009)

19）湯浅昇ほか：各種セメントを用いたコンクリートの 乾燥に伴う内部不均質性、セメント・コンクリート 論文集、No. 49、pp. 60-65（1995）

20）下村和也ほか：早期脱型後の曝露条件がコンクリー トの表層品質に及ぼす影響、土木学会第 63 回年次 学術講演会講演概要集、V-293、pp. 585-586（2008）

21）魚本健人、高田良章：コンクリートの中性化速度 に及ぼす要因、土木学会論文集、No. 451、V-17、 pp. 119-128（1992）

22）蔵重勲、廣永道彦：脱型材齢や曝露環境がコンク リートの強度特性や表層透気性ならびに中性化抵抗 性に及ぼす影響の実験的評価、コンクリート工学年 次論文集、Vol. 32、No. 1、pp. 623-628（2010）

23）三井健郎ほか：反発度法により推定した構造体コン クリート強度に影響する要因、コンクリート工学年 次論文集、Vol. 27、No. 1、pp. 1651-1656（2005）

24) R. J. Torrent and G. Frenzer, "A method for the rapid determination of the coefficient of permeability of the covercrete", Proceedings of the International Symposium Non-Destructive Testing in Civil Engineering (NDT-CE), pp. 985-992 (1995)

25) R. J. Torrent, "A two-chamber vacuum cell for measuring the coefficient of permeability to air of the concrete cover on site, Materials and Structures, Vol. 25, No.6, pp. 358-365 (1992)

\title{
EFFECTS OF DEMOLDING AGE ON THE STRENGTH DEVELOPMENT AND THE CARBONATION RESISTANCE OF LOW-HEAT PORTLAND CEMENT FLY ASH SYSTEM MATERIALS, AND NONDESTRUCTIVE EVALUATIONS OF THEIR SURFACE QUALITIES
}

\author{
Isao KURASHIGE ${ }^{* 1}$, Takahiro NISHIDA ${ }^{* 1}$ and Michihiko HIRONAGA ${ }^{* 1}$
}

*1 CENTRAL RESEARCH INSTITUTE OF ELECTRIC POWER INDUSTRY, Civil Engineering Research Laboratory, Nuclear Fuel Cycle Backend Research Center (1646, Abiko, Abiko-shi, Chiba 270-1194, Japan)

\begin{abstract}
The effects of demolding age on the strength development and the carbonation resistance of low-heat Portland cement fly ash system materials, which have been researched as a candidate material for low-level radioactive waste disposal in Japan, were experimentally examined with the aim of optimizing the curing condition for them. The results show that the longer term until demolding in age from 7 to 28 days is set up, the more the compressive strength and static modulus of elasticity increase. It is found that, in carbonation acceleration tests, the carbonation rates of demolded specimens at 28-day age are reduced by half value of demolded specimens at 7-day age. In addition, it is clarified that the values of nondestructive-measured surface air permeability of specimens correlate to their carbonation rates and surface permeability test may be useful as a method for the inspection of surface quality of casted concrete with low-heat Portland cement fly ash system materials.
\end{abstract}

KEY WORDS : Radioactive waste disposal, Low-heat Portland cement, Fly ash, Demolding age, Strength development, Carbonation resistance, Surface quality, Nondestructive evaluation 